\title{
Influence of Foliar Application of Bio-Regulators and Nutrients on the Fruit Quality of Lemon (Citrus limon Burma.) Cv. Pant Lemon-1
}

\author{
Bharat Bhushan Bhatt*, Krishan Kumar Singh and S.S. Rawat \\ Department of Horticulture, Chauras Campus, HNB Garhwal University, \\ Srinagar (Garhwal) 246174, Uttarakhand, India \\ *Corresponding author
}

\begin{tabular}{|c|c|}
\hline & A B S T R A C T \\
\hline \multicolumn{2}{|l|}{ Keywords } \\
\hline $\begin{array}{l}\text { Lemon, Nutrients, } \\
\text { Bio-regulators, } \\
\text { Foliar application, } \\
\text { Quality }\end{array}$ & \multirow{3}{*}{$\begin{array}{l}\text { An experiment was conducted to study the Influence of foliar application of Bio- } \\
\text { Regulators and Nutrients on the fruit Quality of Lemon (Citrus Limon Burma.) Cv. Pant } \\
\text { Lemon-1 during 2009-10 at HRC (Horticultural Research Centre), Chauras Campus. } \\
\text { H.N.B. Garhwal University Srinagar, Garhwal Uttarakhand, India. The experiment was } \\
\text { conducted in Randomized Block Design with sixteen treatments and replicated in three, } \\
\text { considering one plant as a unit. On the basis of overall performance of treatments on } \\
\text { quality characters of fruits, it can be concluded that the values for fruit length, fruit juice, } \\
\text { total soluble solids, total sugars, shelf-life of fruits, have been obtained maximum, while } \\
\text { the maximum fruit weight, fruit volume, acidity were recorded with NAA ( } 50 \text { ppm). }\end{array}$} \\
\hline Article Info & \\
\hline $\begin{array}{l}\text { Accepted: } \\
\text { 20 March } 2017 \\
\text { Available Online: } \\
10 \text { April } 2017\end{array}$ & \\
\hline
\end{tabular}

\section{Introduction}

India is the sixth largest citrus producing country in the world. Citrus fruits claim to be at third place in area and production after mango and banana with an area of 1042 thousand hectares with a total production of 10090 thousand MT and productivity of about $9.7 \mathrm{MT} / \mathrm{ha}$. These fruits contribute $12.4 \%$ share in total production of fruits in India (NHB, 2012-13). Most of the cultivated species of the citrus fruits are believed to be native of tropical and subtropical regions of South-East Asia stretching from India and China in the North-East up to Australia and New Caledonia in the South-East.

Vitamin-C content of these fruits increases the body resistance to diseases, aids the healing of wounds and prevents damage to the eyes, but deficiency of it causes scurvy disease. These fruits also contain vitamin-P, which keeps the small blood vessels in healthy condition in our bodies and helps in the assimilation of vitamin-C. Because of high nutritive value, medicinal properties and suitability to processing, the consumption of citrus fruits has gone up several folds but the area and production have not increased in same proportion. Therefore, citrus fruits deserve special attention and management for raising the quality production to fulfill the demand of masses.

Among the various practices, the use of bioregulators have been identified to play an important role in modern crop husbandry for increased production of quality fruits through 
improving flowering, fruit set, fruit drop control, fruit shape and size etc. These organic chemical compounds modify the physiological processes of fruit plants when applied in small concentrations. Therefore, there is a need to study the effect of bioregulators along with varied concentrations for above quantitative and qualitative characters of lemon fruits. Nutrition is another important factor affecting the health of the plants. The optimum requirement of nutrition of a particular species or variety greatly varies with soil and agro-climatic conditions. Thus, there is a need to standardize the nutritional requirements for lemons under different agroclimatic conditions. Foliar application of nutrients is an ideal way of evading the problems of nutrient availability and supplementing the fertilizers to the soil. In the semi-arid areas of Garhwal region, the foliar application is the alternative and safe way of applying nutrients for quick absorption and maximum availability.

In view of the above facts, it is clear that the foliar application of bio-regulators and nutrients is very important not only for increasing yield but also to improve the quality of fruits.

Therefore, the present investigation entitled Effect of Foliar Application of Bio-regulators and Nutrients on Yield and Quality of Lemon (C. limon Burma.) cv. Pant Lemon-1 under Subtropical Conditions of Garhwal Region was carried out at Horticultural Research Centre, Chauras, HNB Garhwal University, Srinagar (Garhwal) Uttarakhand with the following objectives to find out the efficacy of different nutrients on yield and quality of lemon fruits through foliar application. And to study the effects of bio-regulators on yield and quality of lemon fruits. Also to standardize the concentrations of bioregulators and nutrients for enhancing yield and quality of lemon fruits.

\section{Materials and Methods}

Geographically, the Department of Horticulture and Horticultural Research Centre, Chauras Campus, H.N.B. Garhwal University, Srinagar (Garhwal), Uttarakhand, is situated at Alaknanda Valley between $78^{0}$ $46^{\prime} 7$ " $\mathrm{N}$ latitude, right in the heart of Garhwal region, $132 \mathrm{~km}$ away from Haridwar on Haridwar Badrinath Dham Highway at an elevation of $540 \mathrm{~m}$ above MSL, in the lesser Himalayan region. The average minimum and maximum temperature, relative humidity and rainfall vary from $6.44^{0} \mathrm{c}$ to $34.7^{0}, 65.24 \%$ and 2.60 to $245.46 \mathrm{~mm}$ respectively. Six-year-old bearing lemon trees of cultivar Pant Lemon-1 of uniform vigour and size were selected for the present study. All the trees were maintained under uniform cultural schedule during the course of investigation. The experiment consisted of sixteen treatments of two bio-regulators and three nutrients, and each one was applied singly and a spray of plain tap water as control. These were, NAA (10 ppm), NAA (25 ppm), NAA (50 ppm), GA3 (10 ppm), GA3 (15 ppm), GA3 (20 $\mathrm{ppm})$, Urea $(0.5 \%)$, Urea $(1.0 \%)$, Urea (2.0\%), Zinc Sulphate (0.2\%), Zinc Sulphate $(0.3 \%)$, Zinc Sulphate $(0.4 \%)$, Borax $(0.2 \%)$, Borax $(0.3 \%)$, Borax $(0.4 \%)$ and Control. Forty eight plants of Pant Lemon-1 were selected for the present study and each tree formed as a unit of treatment. All the treatments were replicated thrice. All the plants selected for the experiment were labelled as per layout of experiment and the sprays of treatment solutions were done on experimental pants of Pant Lemon-1 at full bloom stage (when about $75 \%$ flowers had opened on the selected shoots) during the spring season. The spray was done in morning around 10 AM with the help of hand sprayer at the rate of three liters per plant to ensure the maximum absorption of bio-regulators and nutrients through the leaves. Each tree was sprayed thoroughly in such a way as to 
completely drench it with the spray solution. The experimental data were subjected to ' $F$ ' test as per procedure of Randomized Block Design (RBD) as described by Snedecar and Cochran (1987). The critical difference (C.D.) for each parameter was calculated to compare treatment means at 5 per cent level of significance.

\section{Results and Discussion}

Significant the maximum fruit length $(5.55$ $\mathrm{cm})$ was also recorded under treatment $\mathrm{GA}_{3}$ (20 ppm), while second position was earned by Borax spray $(0.3 \%)$ with $5.42 \mathrm{~cm}$ fruit length. The minimum fruit length $(4.62 \mathrm{~cm})$ was recorded under control. However, the highest breadth of fruit $(5.39 \mathrm{~cm})$ was observed with borax $(0.4 \%)$ and the lowest value $(4.46 \mathrm{~cm})$ under control. Application of NAA (200 ppm) 30 days after full bloom to Unshiu orange trees greatly increased fruit size and the proportion of larger fruits (Nakajima et al., 1969). Babu and Lavania (1985) reported that the maximum length of lemon fruits was recorded with NAA (10 ppm) treatment, followed by (5 ppm and 20 ppm) 2,4-D. Except for the higher concentrations each of NAA and $\mathrm{GA}_{3}$, all other treatments increased the diameter of the fruits. As the concentrations of these three growth regulators increased the fruit length and diameter also increased proportionally. In the present investigations $\mathrm{GA}_{3}$ and borax in higher concentrations increased the fruit length and diameter significantly. Earlier findings of scientists on fruit length and diameter supported the results for this character under present study. The fruit weight was observed highest (110.01 g) with NAA (50 ppm). While, the lowest value for fruit weight $(77.23 \mathrm{~g})$ was exhibited by control. Sprays of 40 ppm 2,4-D to Washington Navel orange increased the fruit weight by $62 \%$ (Keleg and Minessy, 1965). Similarly, Coorg mandarin fruits treated with 25 and 50 ppm 2,4,5-T had
$34 \%$ and $35 \%$ more weight, respectively, over the untreated fruits (Rodrigues and Subramanyam, 1966). An increase in fruit weight with 250-500 ppm NAA was reported by Ali et al., (1973) in kinnow mandarin, when sprayed two weeks after fruit set. Singh and Singh (1981) reported that $\mathrm{GA}_{3}(15 \mathrm{ppm})$ applied once in August, September and October to Kaula mandarin trees increased fruit weight by $30 \%$ over control. All above scientists have reported that NAA and $\mathrm{GA}_{3}$ were found to increase fruit weight in different fruit crops which also encourage the results of the present investigation for these quality parameters. The maximum fruit volume $(108.11 \mathrm{ml})$ was observed with treatment NAA $(50 \mathrm{ppm})$ While, the minimum fruit volume $(76.68 \mathrm{ml})$ was found under control. Reddy and Prasad (2012) reported that the fruit volume was found superior with the application of 2,4-D (40 ppm), followed by $\mathrm{GA}_{3}(75 \mathrm{ppm})$ and NAA (40 ppm) in pomegranate cv. Ganesh. The results obtained for fruit volume under present study are in conformity with the results of earlier workers as mentioned above. Similar observations were recorded by Babu and Lavania (1985) in Pant Lemon-1. The maximum specific gravity (0.98) was observed with control and the minimum specific gravity (0.96) was found under urea $(1.0 \%)$ treatment. The minimum specific gravity of fruits was obtained under urea treatment presumably, because of the effect of urea on the internal quality of the fruits, which affects the weight and volume of the fruits. Guava fruits showed minimum specific gravity when trees were sprayed with zinc sulphate at the rate of $0.4 \%$ concentration (Rawat et al., 2010). The maximum values for fruit juice $(47.33 \%)$ was recorded with treatment $\mathrm{GA}_{3}(20 \mathrm{ppm})$ treatments. However, the minimum value for fruit juice percentage (38.69) was found under control. Babu et al., (1982) investigated the effects of zinc, 2,4-D and $\mathrm{GA}_{3}$ alone or in combination on the fruit 
quality of kagzi lime fruits. Zinc and 2,4-D treatments were found to increase the physical traits and chemical composition of juice. $\mathrm{GA}_{3}$ treatments increased the fresh weight and percentage of juice. Sharma et al., (2003) reported that maximum juice content was obtained with $0.5 \%$ zinc sulphate $+50 \mathrm{ppm}$ gibberellic acid in kagzi lime. Similar observations were findings of Singh and Singh (1981) with the spray of $\mathrm{GA}_{3}(15 \mathrm{ppm})$ of Kaula mandarin.

Table.1 Effect of Foliar application of bio-regulators and nutrients on physical characters of lemon (Citrus limon Burma.) cv. Pant Lemon-1

\begin{tabular}{|c|c|c|c|c|c|c|}
\hline Treatments & $\begin{array}{l}\text { Fruit } \\
\text { length } \\
(\mathrm{cm})\end{array}$ & $\begin{array}{l}\text { Fruit } \\
\text { breadth } \\
\text { (cm) }\end{array}$ & $\begin{array}{l}\text { Fruit } \\
\text { weight } \\
\text { (gm) }\end{array}$ & $\begin{array}{l}\text { Fruit } \\
\text { volume } \\
\text { (ml) }\end{array}$ & $\begin{array}{l}\text { Specific } \\
\text { gravity of } \\
\text { fruits }\end{array}$ & $\begin{array}{l}\text { Peel } \\
\text { thickness } \\
(\mathbf{m m})\end{array}$ \\
\hline $\begin{array}{l}\text { NAA }(10 \\
\text { ppm) }\end{array}$ & 5.13 & 4.91 & 96.95 & 97.12 & 0.972 & 2.26 \\
\hline $\begin{array}{l}\text { NAA }(25 \\
\text { ppm) }\end{array}$ & 5.20 & 5.03 & 106.75 & 106.98 & 0.969 & 2.29 \\
\hline $\begin{array}{l}\text { NAA }(50 \\
\text { ppm) }\end{array}$ & 5.27 & 5.16 & 110.01 & 108.11 & 0.969 & 2.28 \\
\hline $\mathrm{GA}_{3}(10 \mathrm{ppm})$ & 5.29 & 5.13 & 95.89 & 97.27 & 0.969 & 2.19 \\
\hline $\mathrm{GA}_{3}(15 \mathrm{ppm})$ & 5.33 & 5.12 & 101.39 & 100.31 & 0.974 & 2.16 \\
\hline $\mathrm{GA}_{3}(20 \mathrm{ppm})$ & 5.55 & 5.24 & 102.78 & 101.91 & 0.971 & 2.19 \\
\hline Urea $(0.5 \%)$ & 4.95 & 4.71 & 93.57 & 94.43 & 0.968 & 2.35 \\
\hline Urea $(1.0 \%)$ & 5.17 & 5.03 & 93.78 & 94.81 & 0.967 & 2.33 \\
\hline Urea $(2.0 \%)$ & 5.02 & 4.72 & 94.89 & 95.37 & 0.973 & 2.59 \\
\hline $\begin{array}{l}\text { Zinc Sulphate } \\
(0.2 \%)\end{array}$ & 5.15 & 4.95 & 84.88 & 87.41 & 0.977 & 2.66 \\
\hline $\begin{array}{l}\text { Zinc Sulphate } \\
(0.3 \%)\end{array}$ & 5.21 & 5.03 & 85.92 & 84.14 & 0.972 & 2.54 \\
\hline $\begin{array}{l}\text { Zinc Sulphate } \\
(0.4 \%)\end{array}$ & 5.39 & 5.06 & 92.58 & 92.98 & 0.968 & 2.49 \\
\hline Borax $(0.2 \%)$ & 5.13 & 5.89 & 79.84 & 81.11 & 0.969 & 2.38 \\
\hline Borax $(0.3 \%)$ & 5.42 & 5.11 & 82.74 & 83.13 & 0.972 & 2.41 \\
\hline Borax $(0.4 \%)$ & 5.21 & 5.92 & 83.76 & 82.67 & 0.969 & 2.36 \\
\hline Control & 4.62 & 4.45 & 77.23 & 76.68 & 0.981 & 2.72 \\
\hline S.Em. \pm & 0.105 & 0.161 & 4.48 & 4.51 & 0.005 & 0.123 \\
\hline $\mathrm{CD}$ at $5 \%$ & 0.305 & 0.466 & 12.95 & 13.04 & 0.015 & 0.356 \\
\hline
\end{tabular}


Table.2 Effect of Foliar application of bio-regulators and nutrients on chemical characters of lemon (Citrus limon Burma.) cv. Pant Lemon-1

\begin{tabular}{|c|c|c|c|c|c|c|}
\hline Treatments & $\begin{array}{l}\text { Fruit } \\
\text { juice }(\%)\end{array}$ & $\begin{array}{l}\text { Total } \\
\text { soluble } \\
\text { solids (\%) }\end{array}$ & $\begin{array}{l}\text { Acidity } \\
(\%)\end{array}$ & $\begin{array}{l}\text { Vitamin } C \\
(\mathrm{mg} / 100 \mathrm{gm})\end{array}$ & $\begin{array}{l}\text { Total } \\
\text { Sugars } \\
(\%)\end{array}$ & $\begin{array}{l}\text { Shelf- } \\
\text { life of } \\
\text { fruits } \\
\text { (Days) }\end{array}$ \\
\hline NAA $(10 \mathrm{ppm})$ & $\begin{array}{c}42.53 \\
(40.70)\end{array}$ & 6.37 & $\begin{array}{c}5.22 \\
(13.20)\end{array}$ & 21.58 & $\begin{array}{c}0.171 \\
(2.356)\end{array}$ & 25.03 \\
\hline NAA $(25 \mathrm{ppm})$ & $\begin{array}{c}42.89 \\
(40.90)\end{array}$ & 6.45 & $\begin{array}{c}5.49 \\
(13.55)\end{array}$ & 19.69 & $\begin{array}{c}0.173 \\
(2.380)\end{array}$ & 25.34 \\
\hline NAA $(50 \mathrm{ppm})$ & $\begin{array}{c}46.21 \\
(42.82)\end{array}$ & 6.47 & $\begin{array}{c}6.68 \\
(14.97)\end{array}$ & 19.54 & $\begin{array}{c}0.269 \\
(2.972)\end{array}$ & 25.89 \\
\hline $\mathrm{GA}_{3}(10 \mathrm{ppm})$ & $\begin{array}{c}45.22 \\
(42.25)\end{array}$ & 6.46 & $\begin{array}{c}5.71 \\
(13.80)\end{array}$ & 20.11 & $\begin{array}{c}0.167 \\
(2.338)\end{array}$ & 26.02 \\
\hline $\mathrm{GA}_{3}(15 \mathrm{ppm})$ & $\begin{array}{c}46.51 \\
(42.99)\end{array}$ & 6.54 & $\begin{array}{c}5.35 \\
(13.37)\end{array}$ & 20.37 & $\begin{array}{c}0.281 \\
(3.037)\end{array}$ & 26.59 \\
\hline $\mathrm{GA}_{3}(20 \mathrm{ppm})$ & $\begin{array}{c}47.33 \\
(43.46)\end{array}$ & 6.59 & $\begin{array}{c}5.37 \\
(13.39)\end{array}$ & 19.43 & $\begin{array}{c}0.299 \\
(3.134)\end{array}$ & 26.75 \\
\hline Urea $(0.5 \%)$ & $\begin{array}{c}43.51 \\
(41.26)\end{array}$ & 6.51 & $\begin{array}{c}5.71 \\
(13.82)\end{array}$ & 21.50 & $\begin{array}{c}0.119 \\
(1.969)\end{array}$ & 23.45 \\
\hline Urea $(1.0 \%)$ & $\begin{array}{c}42.87 \\
(40.89)\end{array}$ & 6.38 & $\begin{array}{c}5.74 \\
(13.85)\end{array}$ & 21.07 & $\begin{array}{c}0.124 \\
(2.007)\end{array}$ & 23.67 \\
\hline Urea $(2.0 \%)$ & $\begin{array}{c}42.86 \\
(40.89)\end{array}$ & 6.19 & $\begin{array}{c}5.74 \\
(13.86)\end{array}$ & 20.58 & $\begin{array}{c}0.151 \\
(2.206)\end{array}$ & 23.92 \\
\hline $\begin{array}{l}\text { Zinc Sulphate } \\
(0.2 \%)\end{array}$ & $\begin{array}{c}43.49 \\
(41.25)\end{array}$ & 6.34 & $\begin{array}{c}5.32 \\
(13.33)\end{array}$ & 19.53 & $\begin{array}{c}0.141 \\
(2.135)\end{array}$ & 24.02 \\
\hline $\begin{array}{l}\text { Zinc Sulphate } \\
(0.3 \%)\end{array}$ & $\begin{array}{c}42.87 \\
(40.89)\end{array}$ & 5.97 & $\begin{array}{c}5.69 \\
(13.79)\end{array}$ & 19.40 & $\begin{array}{c}0.159 \\
(2.269)\end{array}$ & 24.28 \\
\hline $\begin{array}{l}\text { Zinc Sulphate } \\
(0.4 \%)\end{array}$ & $\begin{array}{c}41.88 \\
(40.32)\end{array}$ & 5.76 & $\begin{array}{c}5.62 \\
(13.71)\end{array}$ & 19.17 & $\begin{array}{c}0.179 \\
(2.407)\end{array}$ & 24.53 \\
\hline Borax $(0.2 \%)$ & $\begin{array}{c}43.87 \\
(41.47)\end{array}$ & 6.06 & $\begin{array}{c}5.59 \\
(13.67)\end{array}$ & 19.67 & $\begin{array}{c}0.134 \\
(2.088)\end{array}$ & 23.24 \\
\hline Borax $(0.3 \%)$ & $\begin{array}{c}41.67 \\
(40.18)\end{array}$ & 5.57 & $\begin{array}{c}5.73 \\
(13.84)\end{array}$ & 19.98 & $\begin{array}{c}0.146 \\
(2.184)\end{array}$ & 23.67 \\
\hline Borax $(0.4 \%)$ & $\begin{array}{c}44.36 \\
(41.75)\end{array}$ & 5.69 & $\begin{array}{c}5.52 \\
(13.57)\end{array}$ & 19.54 & $\begin{array}{c}0.149 \\
(2.204)\end{array}$ & 23.68 \\
\hline Control & $\begin{array}{c}38.69 \\
(38.42)\end{array}$ & 5.21 & $\begin{array}{c}4.96 \\
(13.83)\end{array}$ & 18.93 & $\begin{array}{c}0.117 \\
(1.958)\end{array}$ & 19.37 \\
\hline S.Em. \pm & $\begin{array}{c}0.80 \\
(0.47)\end{array}$ & 0.153 & $\begin{array}{c}0.144 \\
(0.185)\end{array}$ & 0.509 & $\begin{array}{c}0.012 \\
(0.091)\end{array}$ & 0.70 \\
\hline $\mathrm{CD}$ at $5 \%$ & $\begin{array}{c}2.31 \\
(1.36)\end{array}$ & 0.443 & $\begin{array}{c}0.416 \\
(0.534)\end{array}$ & 1.472 & $\begin{array}{c}0.036 \\
(0.264)\end{array}$ & 2.03 \\
\hline
\end{tabular}


The maximum peel thickness $(2.72 \mathrm{~mm})$ was observed with control, while the minimum peel thickness $(2.16 \mathrm{~mm})$ was obtained with $\mathrm{GA}_{3}$ (15 ppm), Sharma et al., (2003) reported that the maximum juice content and the minimum peel thickness was obtained with $0.5 \%$ zinc sulphate $+50 \mathrm{ppm}$ gibberellic acid in kagzi lime. Bhat et al., (2006) also observed the maximum juice content and the minimum peel thickness in Eureka lemon when sprayed with $\mathrm{GA}_{3}$ in different concentrations. These findings of above scientists with respect to peel thickness match with the results of present study (Table.1).

The highest total soluble solid $(6.59 \%)$ was found with treatment $\mathrm{GA}_{3}(20 \mathrm{ppm})$. The second highest value $6.54 \%$ was recorded under $\mathrm{GA}_{3}$ (15 ppm). Significant increase in TSS over control was recorded with the sprays of $\mathrm{GA}_{3}(250-1000 \mathrm{ppm})$ at full bloom stage in Sweet lime Kumar et al., (1975), and sprays of $\mathrm{GA}_{3}(50-100 \mathrm{ppm})$ in Washington Naval orange (Deidda, 1971). Similarly, sprays of 2,4-D or 2,4,5-T have been reported to increase the TSS in Lahore local (Singh and Randhawa, 1961) and Kinnow mandarins (Chundawat et al., 1975). Malik et al., (2000) found the significant increase in total soluble solids with receiving $1 \%$ urea spray and $0.8 \%$ zinc sulphate separately or in combination in mandarin hybrid trees. All these findings of different workers and scientist are justifying the results obtained for total soluble solids under present investigation. The maximum acidity percentage $(6.68 \%)$ was also observed with treatment NAA (50 ppm). The second highest value for acidity $(5.74 \%)$ was shown by spray of urea at $1.0 \%$. Phillips and Meagher (1967) observed an increase in acidity with sprays of 20 ppm 2,4-D or 2,4,5$\mathrm{T}$ in pineapple orange, when sprayed three months before harvest. Similarly, in Unshiu orange, an application of NAA (200 ppm), 30 days after full bloom has been reported to increase the acidity of the juice (Nakajima $e t$ al., 1969). Joshan et al., (1995) also reported that the acid content was maximum under $6 \%$ and $8 \% \quad \mathrm{~K}_{2} \mathrm{SO}_{4}$ treatments in lemon. The maximum vitamin $\mathrm{C}$ content $(21.06 \mathrm{mg} / 100 \mathrm{~g}$ of fruit juice) was recorded under treatment NAA (10 ppm), followed by $20.93 \mathrm{mg} / 100 \mathrm{~g}$ of fruit juice with urea (0.5\%). Kumar et al., (1975) also reported that the ascorbic acid content was increased significantly in all the sprayed fruits. However, the maximum increase was obtained in fruits treated with PCPA at 100 ppm and 2,4-D at $7.5 \mathrm{ppm}$ in Sweet lime. The ascorbic acid content in fruits was estimated to be highest in fruits treated with NAA (20 ppm), which was closely followed by Mumaur and the lowest under control in aonla cv. NA-10 (Ghosh et al., 2009). Findings of earlier works carried out by various scientists with respect to vitamin $\mathrm{C}$ completely match with the results of the present study. The results are in closed conformity with the findings of Singh et al., (2007) in aonla. The total sugar content $(0.29 \%)$ was observed to be the highest under treatment $\mathrm{GA}_{3}(20 \mathrm{ppm})$, followed by $0.28 \%$ with $\mathrm{GA}_{3}(15 \mathrm{ppm})$, while the minimum total sugar content $(0.11 \%)$ was recorded under control. Ram and Bose (1994) reported that the mandarin orange treated with $600 \mathrm{~g}$ urea as soil application $+1.5 \%$ foliar application and spray of $\mathrm{ZnSO}_{4}(0.5 \%)$ contained more total sugars as compared to control plants. All these findings of different scientists are justifying the results of present investigation with regard to total sugars. Similar observations were recorded by Singh and Singh (1981) in Kaula mandarin.

The data related to shelf-life of fruits indicated that the maximum shelf- life (26.39 days) of fruits was observed with treatment $\mathrm{GA}_{3}$ (20 ppm), However, the minimum shelflife (19.34 days) of fruits was found under control. Brahmachari et al., (1999) reported that the spray of $\mathrm{GA}_{3}$ (50 and $\left.100 \mathrm{ppm}\right)$, Kinetin (20 and 40 ppm), CCC (500 and 1000 ppm) $\mathrm{MH}$ (500 and $1000 \mathrm{ppm}$ ), calcium 
nitrate (1 and 2\%) and borax (0.4 and $0.8 \%)$ 15 days before harvest extended the shelf-life of Purbi litchi fruits as compared to control. Choudhary and Dhaka (2005) reported that gibberellic acid and their combinations were found to prolong the shelf-life of kinnow fruits. All above earlier findings reported by different scientists are almost similar to the results obtained under present study with regards the shelf-life of fruits of Pant Lemon1(Table.2).

It is concluded on the basis of overall performance of treatments on quality characters of fruits, it can be concluded that the values for fruit length, fruit juice, total soluble solids, total sugars, shelf-life of fruits, have been obtained maximum, while the maximum fruit weight, fruit volume, acidity were recorded with NAA (50 ppm). However, the maximum vitamin $\mathrm{C}$ was recorded under NAA (10 ppm) foliar application.

\section{References}

Ali, N., Asi, A.A. and Zahid, N.A. 1973. Induction of regular cropping in citrus with plant growth regulators. Pakistan J. Agric. Res., 8 (3-4): 1-17.

Babu, G.H.V.R. and Lavania, M.L. 1985. Effect of plant growth regulators on fruit set and fruit drop of Pant Lemon1. Indian J. Hort., 42 (2): 237-240.

Bhat, A., Kher, R. and Gupta, S.P. 2006. Effect of growth regulators and nutrients on fruit cracking and fruit quality in lemon. Haryana J. Hort. Sci., 35 (3-4): 267.

Brahmachari, V.S., Kumar, R. and Rani, R. 1999. Effect of pre-harvest application of different chemical on shelf-life of litchi fruits. Haryana J. Hort. Sci., 28 (3-4): 182-185.

Choudhary, M.R. and Dhaka, R.S. 2005. Effect of different post-harvest treatments on quality of kinnow mandarin fruits during storage. Haryana J. Hort. Sci., 34 (1-2): 39-41

Chundawat, B.S., Gupta, O.P. and Arora, R.K. 1975. Studies on fruit drop in Kinnow- A mandarin hybrid cultivar. Haryana J. Hort. Sci., 4 (3-4): 11-15.

De, L.C. and Bhattacharjee, S. K. 2008. Handbook of Edible Fruits. Aavishkar Publishers and Distributors, Jaipur (Raj.), India.

Deidda, P. 1971. The effect of gibberellic acid on fruit set, productivity and fruit characterstics of Washington Navel oranges. Studi Sassaresi., 19: 264-275

Ghosh, S.N., Bera, B., Roy, S., Kundu, A. and Dutta Roy, S.K. 2009. Effect of nutrients and plant growth regulators on fruit retention, yield and physicochemical characteristics in aonla cv. NA-10. J. Hort. Sci., 4 (2): 164-166.

Josan, J.S., Sandhu, A.S., Singh, R. and Dhillon, 1995. Effect of plant growth regulators and nutrients on fruit cracking in lemon. Indian J. Hort., 52 (2): 121-124.

Keleg, F.A. and Minessy, F.A. 1965. Effect of 2,4-D on June drop, pre-harvest drop, fruit quality and alternate bearing in Balady mandarin and Washington Navel orange. Alex. J. Agric. Res., 12 (2): 47-72.

Kumar, R., Singh, J.P. and Gupta, O.P. 1975. Effect of growth regulators on fruit set, fruit drop and quality of Sweet lime (Citrus lamettioides Tanaka.). Haryana J. Hort. Sci., 4 (3-4): 123129.

Malik, R.P., Ahlawat, V.P. and Nain, A.S. 2000. Effect of foliar spray of urea and zinc sulphate on yield and fruit quality of Kinnow- A mandarin hybrid. Haryana J. Hort. Sci., 29 (12): 37-38.

Nakajima, T., Wanago, M. and Ogaki, C. 1969. Practical studies on the use of 
naphthalene acetic acid for thinning the fruits of Unshiu orange trees. Bull. Kangawa. Hort. Exp. Sta., 17: 9-17.

Phillips, R.L. and Meagher, W.R. 1967. Physiological effect and chemical residues resulting from 2,4-D and 2,4,5-T sprays used for control of preharvest fruit drop in Pineapple oranges. Proc.Fla.St.Hort. Soc., 79: 75-79.

Ram, R.M. and Bose, T.K. 1994. Effect of foliar spray on fruit and zinc on growth and yields of Mandarin orange (Citrus reticulata Blanco.). Haryana J. Hort. Sci., 51 (3): 266-271.

Rawat, V., Tomar, Y.K., and Rawat, J.M.S. 2010. Influence of foliar application of micronutrients on the fruit quality of guava cv. Lucknow-49. J. Hill Agri., 1 (1): 63-66.

Reddy, P.A. and Prasad, D.M. 2012. Effect of plant growth regulators on fruit characters and yield of pomegranate (Punica granatum L.). cv. Ganesh. International J.Plant, Animal Environ. Sci., 2 (2): 91-93.

Rodrigues, J. and Subramanyam, H. 1966. Effect of pre-harvest spray of plant growth regulators on size, composition and storage behaviour of Coorg mandarin (C. reticulata Blanco.). $J$. Sci. Fd. Agric., 17: 425-427.

Sharma, A.K., Singh, K. and Mishra, S.P. 2003. Effect of foliar spray of zinc sulphate, 2,4,5-T and $\mathrm{GA}_{3}$ on quality of Kagzi lime (Citrus aurantifolia Swingle.). Orissa J. Hort., 31 (2): 2932.

Singh, J.K., Prasad, J. and Singh, H.K. 2007. Effect of micronutrients and plant growth regulators on yield and physico-chemical characteristics of aonal fruits in NA-10. Indian. J. Hort., 64 (2): 216-218.

Singh, J.P. and Randhawa, S.S. 1961. Effect of plant growth regulators on fruit drop, size and quality in mandarin (Citrus reticulata blanco). var. Nagpuri and Lahor local, Indian J. Hort., 18 (1): 285-294.

Singh, R. and Singh, R. 1981. Effect of $\mathrm{GA}_{3}$ Planofix (NAA) and Ethral on granulation and fruit quality in Kaula mandarin. Scientia Hort., 14 (4): 315321.

Snedecor, G.W. and Cochran, G.W. 1987. Statistical Methods. $6^{\text {th }}$ Edn. Oxford and IBH, New Delhi.

\section{How to cite this article:}

Bharat Bhushan Bhatt, Krishan Kumar Singh and Rawat, S.S. 2017. Influence of Foliar Application of Bio-Regulators and Nutrients on the Fruit Quality of Lemon (Citrus limon Burma.) Cv. Pant Lemon-1. Int.J.Curr.Microbiol.App.Sci. 6(4): 2451-2458. doi: https://doi.org/10.20546/ijcmas.2017.604.286 